\title{
NITRATE POLLUTION IN GROUND WATER OF KALPITIYA: AN EVALUATION OF THE CONTENT OF NITRATES IN THE WATER AND FOOD ITEMS CULTIVATED IN THE AREA
}

\author{
C.E. LIYANAGE ${ }^{1 *}$, M.I. THABREW ${ }^{2}$ and D.S.P. KURUPPUARACHCHI ${ }^{3}$ \\ ${ }^{I}$ Department of Commuinity Medicine, Faculty of Medicine, University of Ruhuna, Galle. \\ ${ }^{2}$ Department of Biochemistry and Clinical Chemistry, Faculty of Medicine, University of \\ Kelaniya, Kelaniya. \\ "Agricultural Research Centre, Makandura.
}

(Received: 16 August 1999 ; accepted: 06 October 2000)

\begin{abstract}
A high intake of nitrates or nitrites is known to be hazardous to health. An analysis of drinking water from 225 wells in 11 Family Health Worker Areas in the Kalpitiya peninsula showed that only $56 \%$ of these wells contain nitrate concentrations considered to be safe by the WHO $(<50 \mathrm{mg}$ nitrate $/ 1)$. $31 \%$ per cent; of these wells contain a nitrate concentration hetween $50 \mathrm{mg} / \mathrm{l}$ and $100 \mathrm{mg} / \mathrm{l}$ while the balance $17.4 \%$ contain very high nitrate concentrations ranging from $101-300$ $\mathrm{mg} /$. An analysis of 7 types food items commonly grown in the peninsula (sweet potato - Ipomaea batatas, kurathampala-Amaranthus viridis, gherkins - Cucumis sp, anguna leaves-Timonius jarmbosella, red onions-Allium cepa, potatoes Solanum tuberosum. and long heans - Vigna cyindrica) revealed that anguna leaves, long heans and kurathampala contain high nitrate concentrations $(2.79 \mathrm{~g} / \mathrm{kg}, 1.15 \mathrm{~g} / \mathrm{kg}$ and $3.25 \mathrm{~g} / \mathrm{kg}$ respectively) on a wet weight basis. Of these, anguna leaves is one vegetable known to be eaten daily by majority of the local population. From calculations based on the average daily intake of anguna leaves (approximately $100 \mathrm{~g}$ ) and water (31) it is apparent that a person living in an area with wells containing $>100 \mathrm{mg}$ nitrate/ would consume close to $600 \mathrm{mg}$ nitrate/ day. If the contribution from other vegetables consumed is also taken in to account, the daily nitrate intake of these individuals would be even higher. Therefore it is possible that high nitrate levels in the vegetahles grown and water available in the Kalpitiya peninsula may attribute to the development of toxic methaemoglobinaemia in people living in the area.
\end{abstract}

Key words: Ground water pollution, Kalpitiya peninsula, methaemoglobinaemia, nitrate, nitrite.

\section{INTRODUCTION}

Nitrate is considered to be one of the very important water pollutants today. ${ }^{1}$ The sources of nitrate are both natural and anthropogenic. According to published reports ${ }^{2}$, during the past two decades, nitrate levels in ground water of many countries has increased significantly because of the increased use of nitrogenous fertilizers. Such practices also result in increased exposure of man and animals to high concentrations of nitrates in food, feed ${ }^{3}$ and water, as nitrates can be incorporated into plants grown in soils containing high concentrations of

\footnotetext{
" Corresponding author
} 
this chemical. ${ }^{4}$ The increase of nitrate in plants will be more rapid as the quantity of fertilizer applied to the soil increases. ${ }^{5}$ The wide presence of nitrates and nitrites in substantial quantities in soil, water and plants (including vegetables) has been a matter of concern in many developing countries. ${ }^{4}$ According to Sudrand et $a l^{5}$, the nitrate content of vegetables grown under intense cultivation with the use of fertilizers is very much higher than the physiological optimum that can be safely tolerated by humans.

Consumption of abnormally high concentrations of nitrates and nitrites is known to be deleterious to health. "4; For example, methaemoglobinaemia can develop due to the oxidation of the iron (II) of blood haemoglobin to the iron (III) state. ${ }^{6}$ Single oral doses of $2-4$ g nitrate or $60-500 \mathrm{mg}$ nitrite ${ }^{7}$ have been shown to produce toxic methaemoglobinaemia in humans. The lethal dose range in human adults is $4-50 \mathrm{~g}$ for nitrate and $1.6-9.5 \mathrm{~g}$ for nitrite. ${ }^{7}$. Naturally occurring nitrites or those produced from nitrates ${ }^{6.8}$ can also give rise to toxic nitrosamines that have been implicated in the development of various cancers. ${ }^{4}$ Thus concern with nitrates in the environment is related in part to its conversion by biological systems to nitrite. In view of the clinical implications of abnormal nitrate and nitrite concentrations it is important to estimate the concentrations of these chemicals in different types of vegetables and other foods grown under intense cultivation with a view to subsequently controlling the concentrations of these chemicals incorporated into such food items. ${ }^{9}$ Although the concentrations of nitrate and nitrite in food items of many countries have been established ${ }^{10 \cdot 12}$, there are no reports of similar studies having been carried out in Sri Lanka.

Kalpitiya is a low-lying sand peninsula in Sri Lanka which has a closed aquifer and is intensively cultivated with food crops. Coconut plantations are still the principal crop grown in Kalpitiya, although in recent years there has been a siguificant expansion of intensive horticulture. Onions, chillies and potatoes are the most important crops but other vegetables such as gherkins, okra and. aubergines are also grown. The farms, which are typically small holdings of 0.5 - 1.0 ha were brought into production following the clearance of scrub waste-land.

The geological succession on the Kalpitiya peninsula consists of regosols ${ }^{13}$ overlying some $15-20 \mathrm{~m}$ of fine coarse sands of marine origin. Beneath the sands are clays which in turn overlie a Miocene limestone. A thin fresh water lens occurs in the sands and is present at depths of 1 -3m over most of the peninsula. ${ }^{14}$ Ground water that occurs in the limestone is more saline than that in the phreatic sand aquifer and, as a consequence, is not developed for water supply. The phreatic aquifer is extensively pumped for both irrigation and potable water supplies, there being no other source of fresh water available. Recharge is by direct infiltration from both rainfall and return irrigation flows. Prior to the introduction of irrigated agriculture, groundwater flow under the peninsula would have been to the sea and the lagoon. However, development of the shallow aquifer has altered the natural flow regime and now groundwater flow within the phreatic aquifer is dominated 
by obstruction from the shallow open irrigation wells. ${ }^{35}$ The soils of the peninsula are extremely permeable, consisting of $90-98 \%$ sand; hence there are no problems with drainage or water logging. Due to the intensive cultivation throughout the year, a large amount of chemical fertilizer is used by the farmers to increase the crop output. Due to the increasing application of nitrogenous fertilizer in a closed aquifer, the population of the area is in danger of consuming potentially harmful concentrations of nitrates through their food and water. The nitrate content in water and food items consumed by the population living in the Kalpitiya peninsula have therefore been investigated with a view to determining their average daily intake of nitrates.

\section{METHODS AND MATERIALS}

Area and collection of samples for analysis: Kalpitiya is a low-lying area in the North West of Sri Lanka having a significant expansion of intensive horticulture. The samples of water for analysis were collected from shallow open wells used both for irrigation and domestic purposes in the Peninsula. A statistically significant number of drinking water wells (225) from all (11) the Family Health Worker Areas (FHWA) of the peninsula were selected randomly and 3 samples of water from each well were collected using a bucket from the middle of the well. The samples of water were transported in plastic bottles to the laboratory and analysed on the same day.

Of the different food crops cultivated in the Peninsula 7 types namely sweet potatoes (Ipomaea batatas), red onions (Allium cepa), potatoes (Solanum tuberosum), gherkin (Cucumis sp), anguna leaves (Timonius jambosella), kurathampala (Amaranthus viridis) and long beans (Vigna cylinrica), that were extensively grown throughout were selected to determine the nitrate content. One hundred and fifty grams of each type were collected from each FHWA and transported to the laboratory. The composite samples made for each food type were then weighed and stored for analysis. Information on the types of food eaten most frequently and the average daily intake of these items and drinking water consumed by the population of the area were recorded by means of a dietary survey by recall.

Reagents: All the reagents used were of AnalaR grade and purchased from Sigma Chemical Co. Ltd, Poole, Dorset, UK.

Estimation of nitrate content in samples of drinking water: The water samples were analysed using a Nitrate electrode (Orion meter with specific ion electrode - Mode 93-07/dobule junction reference electrode, Mode 90/02). For quality control purposes, $10 \%$ of samples randomly selected were also analysed by a more accurate ion chromatography method, using an ion liquid chromatograph - model 1LC-1, waters with IC - Anion Column. 
Estimation of nitrate content in food items under investigation: The food items were analysed by a distillery method as described by Piper(1950). ${ }^{16}$ Each composite was cut into small pieces not more than half a centimeter and $250 \mathrm{~g}$ from each weighed on a flat tray. Another two small samples of $150 \mathrm{~g}$ from each food composite were also weighed and dried for moisture determination. The test samples were dried rapidly in an oven at $55 \mathrm{C}^{\circ}$ for $12-16 \mathrm{~h} .300 \mathrm{ml}$ distilled water containing $10 \mathrm{drops}$ of Conc. $\mathrm{H}_{2} \mathrm{SO}_{4}$ were poured to cover the dried plant material, and the mixture was filtered through a Buchner funnel fitted with a Whatman No.50 filter paper and connected to a pressure pump. The residue on the filter paper was washed 4 times with successive quantities of distilled water, until the filtrate amounted to $600 \mathrm{ml}$. The filtrate was then transferred to a 1 litre Erlenmeyer flask, $1 \mathrm{~g}$ of $\mathrm{MgO}$ added and evaporated until the volume was reduced to $200 \mathrm{ml}$. Once cold, $2 \mathrm{~g}$ of Devarda's alloy and $70 \mathrm{ml}$ of $30 \% \mathrm{NaOH}$ were added. The flask was then connected to the condenser of a nitrogen distillation unit through an efficient splash trap. The reduction was allowed to proceed, firstly in the cold for half an hour, secondly over a very small flame for another half an hour and thirdly, the ammonia was boiled off in the next half an hour. The ammonia was collected in $10-35 \mathrm{ml}$ of $0.02 \mathrm{~mol} \mathrm{\textrm {dm } ^ { - 3 }}$ $\mathrm{HCl}$ and the excess of acid titrated with $0.02 \mathrm{~N} \mathrm{NaOH}$ using methyl red. The amount of nitrate nitrogen in $\mathrm{mg}$ per $\mathrm{kg}(\mathrm{ppm})$ on a dry weight basis was calculated, and the data were presented on a wet weight basis. To establish the percentages of recovery from samples, 5 different samples spiked with pure nitrate solution were processed as above, and the mean recovery was $86 \%$. Coefficient of variation was $3.8 \%$.

Statistical analysis: The statistical analysis was carried out by means of Students t-test.

\section{RESULTS}

\section{Nitrate content in drinking water}

As evident from Table 1, of the 225 wells under investigation only $51 \%$ had water with a nitrate content of less than $50 \mathrm{mg} / \mathrm{l}$ which is the WHO recommended safe upper limit." Water samples in about $31 \%$ of the wells had nitrate concentrations between 51 and $100 \mathrm{mg} / \mathrm{l}$, while the rest of the wells contained even higher nitrate concentrations extending up to $300 \mathrm{mg} / \mathrm{l}$. A comparison of duplicate samples suggests that the nitrate concentrations obtained by using the ion selective electrode are statistically correlated $\left(\mathrm{r}^{2}=0.98\right)$ with the results produced by ion-chromatigraphy method (Fig. 1). A comparison of mean nitrate concentration in each of the category of wells (with respect to nitrate) under study with the nitrate concentrations reported in the North Western Province (NWP) ${ }^{17}$ and in the Jaffna peninsula, ${ }^{18}$ indicates that there is a significant difference in the nitrate content in the Kalpitiya waters(Table $2 \mathrm{a} \& \mathrm{~b}$ ). Thus the mean nitrate levels of all the different categories of waters in the Kalpitiya peninsula were significantly 
higher than the nitrate content of waters of the North Western Province and the domestic wells in Jaffna. About $12 \%$ of the wells analysed in the Kalpitiya peninsula also had markedly higher nitrate levels than those reported for farm wells in Jaffna.

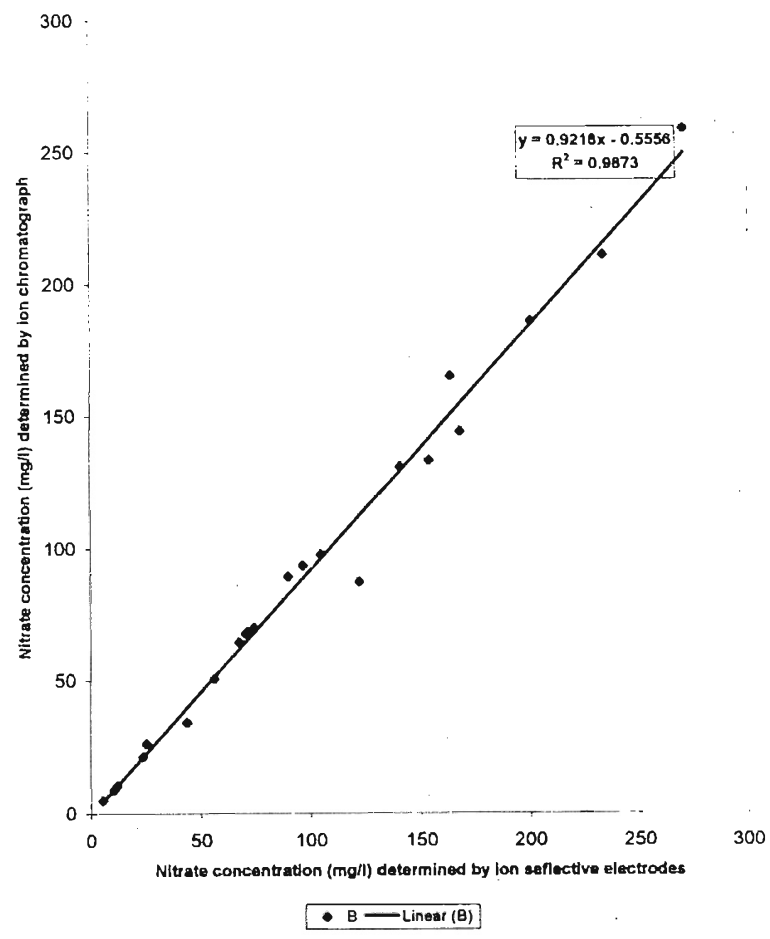

Figure 1: Comparison of nitrate concentration obtained from specific ion-electrodes and by ion-chromatography

Table 1: Nitrate content in drinking water at Kalpitiya

\begin{tabular}{lcrccc}
\hline $\begin{array}{l}\text { Nitrate } \\
\text { category }\end{array}$ & $\begin{array}{c}\text { Concentration } \\
(\mathrm{mg} / \mathrm{l})\end{array}$ & \multicolumn{2}{c}{$\begin{array}{c}\text { No. \& \% of } \\
\text { wells }\end{array}$} & $\begin{array}{c}\text { Mean nitrate } \\
\text { content }(\mathrm{mg} / \mathrm{l})\end{array}$ & SD \\
\hline low & $<50$ & 116 & 51.56 & 31.30 & \pm 10.03 \\
intermediate & $50-100$ & 68 & 30.22 & 72.66 & \pm 13.18 \\
high & $101-150$ & 22 & 9.78 & 121.40 & \pm 12.93 \\
very high & $151-200$ & 11 & 4.89 & 175.65 & \pm 16.85 \\
& $201-250$ & 4 & 1.78 & 228.31 & \pm 12.61 \\
& $251-300$ & 3 & 1.33 & 283.33 & \pm 24.73 \\
\hline
\end{tabular}


Table 2a: A comparison of the mean nitrate content $\pm S D$ of different categories ( with respect to nitrate) of well water in Kalpitiya with waters in the North Western Province (NWP.) and the Jaffna peninsula.

\begin{tabular}{lccc}
\hline Category (mg/1) & No. of Wells & $\begin{array}{c}\text { Mean nitrate } \\
\text { content (mg/) }\end{array}$ & SD \\
\hline Kalpitiya & & & \\
$\quad$ Low (<50) & 116 & 31.30 & \pm 10.03 \\
Intemediate (50-100) & 68 & 72.66 & \pm 13.18 \\
High (101-150) & 22 & 121.40 & \pm 12.93 \\
Very high (151-200) & 11 & 175.65 & \pm 16.85 \\
$\quad 4$ & 228.31 & \pm 12.61 \\
$\quad(201-250)$ & 3 & 283.33 & \pm 24.73 \\
$\quad$ * & $451-300)$ & 7.18 & \pm 4.57 \\
${ }^{* *}$ Jaffna (farm wells) & 7 & 134.68 & \pm 49.78 \\
$\quad$ (domestic wells) & 4 & 4.52 & \pm 4.46 \\
\hline
\end{tabular}

"Ref. 17, "Ref. 18

Table 2b: Difference \& significance between mean nitrate level of each category of Kalpitiya and that of NWP and Jaffna (farm \& domestic).

\begin{tabular}{|c|c|c|c|c|c|c|}
\hline \multirow{3}{*}{$\begin{array}{l}\text { Kalpitiya } \\
\text { categories }\end{array}$} & \multicolumn{2}{|c|}{ NWP } & \multicolumn{4}{|c|}{ Jaffna } \\
\hline & \multirow[b]{2}{*}{ difference } & \multirow[b]{2}{*}{ p.value } & \multicolumn{2}{|c|}{ farm } & \multicolumn{2}{|c|}{ domestic } \\
\hline & & & difference & p.value & difference & p. value \\
\hline 1 & 24.12 & 0.000087 & -103.38 & 0.058 & 26.78 & 0.000001 \\
\hline 2 & 65.48 & 0.00 & -62.02 & 0.119 & 68.14 & 0.00 \\
\hline 3 & 114.22 & 0.000001 & -13.28 & 0.435 & 116.88 & 0.00 \\
\hline 4 & 168.47 & 0.000197 & 40.97 & 0.197 & 171.13 & 0.00 \\
\hline 5 & 221.13 & 0.0978 & 93.63 & 0.066 & 223.79 & 0.00 \\
\hline 6 & 276.13 & 0.048 & 148.65 & 0.000431 & 278.81 & 0.0481 \\
\hline
\end{tabular}


Table 3: Nitrate content of vegetable products grown in the Kalpitiya peninsula

\begin{tabular}{|c|c|c|}
\hline \multirow[t]{2}{*}{ Vegetable } & \multicolumn{2}{|c|}{ Nitrate concentration } \\
\hline & $\begin{array}{l}\text { dry weight } \\
\text { (mg/lkg) }\end{array}$ & $\begin{array}{c}\text { wet weight } \\
(\mathrm{mg} / \mathrm{kg})\end{array}$ \\
\hline Sweet potatoes & 928.1 & 193.7 \\
\hline Onions & 4217.6 & 923.5 \\
\hline Potatoes & 2869.3 & 466.2 \\
\hline Gherkin & $1,9660.0$ & 884.7 \\
\hline Anguna leaves & $1,4449.2$ & 2714.7 \\
\hline Kurathampa]a & $1,8069.7$ & 3252.4 \\
\hline Long beans & $1,0387.6$ & 1142.5 \\
\hline
\end{tabular}

\section{Nitrate content of food items}

Results in Table 3 show that all the foods analysed in the present study contained high nitrate concentrations. Anguna leaves, kurathampala and long beans contained the highest nitrate concentrations. When estimated on a wet weight basis the approximate nitrate content per $100 \mathrm{~g}$ in Anguna leaves, Kurathampala and long beans were $300 \mathrm{mg}, 325 \mathrm{mg}$ and $115 \mathrm{mg}$ respectively.

\section{DISCUSSION}

The potential health implications of the contamination of drinking water by nitrates have attracted scientific attention since 1945 , primarily in connection with methaemoglobinaemia. In a study on distribution of nitrates in potable waters in Sri Lanka ${ }^{21}$ high levels have been found in and around main cities indicating a possible relationship with the population density. In the Jaffna peninsula, the groundwater contamination has been shown to be very high ${ }^{29}$, the nitrate levels exceeding WHO limits by $100-150 \%$ in certain locations. This is attributed to the abundant nitrogenous waste matter in the form of human excreta and synthetic and animal fertilizer reaching the shallow groundwater table aided by the surface limestone aquifer, and these geological conditions have been shown to be ideal for the excessive accumulation of nitrates. In a study on pollution of the coastal aquifers of Sri Lanka, the latrine soakways have been suggested ${ }^{21}$ to be the most probable responsible factor for the elevated nitrates, and the pathogens derived from the soakways as the more likely cause of infant mortality rates. However, the elevated nitrate levels were also considered to be 
due to leaching of nitrogenous fertilizers from paddy lands and intensively cultivated soils and a correlation between nitrate concentration and infant mortality rate has been suggested. ${ }^{19}$

In the Kalpitiya peninsula, monitoring of irrigation wells showed a clear correlation of ground water quality with land use. ${ }^{22}$ Groundwater within the intensively cultivated area typically had nitrate concentrations in the range of $10-15 \mathrm{mg} \mathrm{l}^{-1}$ compared to $0.2 \mathrm{mg}^{-1}$ within the non-cultivated lands. These latter concentrations were assumed to be the background concentrations prior to cultivation. It has been observed that the nitrate applied to the soil is washed down rapidly in to the water table during the periods of excessive rainfall/irrigation and that this plume of nitrate rich water migrates to the dug well as a pulse with little dispersion with the aquifer. The water from the irrigation well is then spread over the cropped area where most of the applied water returns to the water table.

In view of the lack of soil humus at Kalpitiya, high rates of nutrient inputs are required; the recommended rates are $200-250 \mathrm{~kg} / \mathrm{ha}$ per crop as $\mathrm{N}, \mathrm{P}_{2} \mathrm{O}_{5}$ and $\mathrm{K}_{2} \mathrm{O} .{ }^{21}$ The recommended fertilizers used are urea and various ammonium compounds (for nitrogen), triple super-phosphate (for phosphate) and muriate of potash (for potassium). Ammonium fertilizers were the most popular source of nitrogen.

The present investigation has revealed that a large percentage of the population living in the Kalpitiya peninsula are in danger of ingesting high concentrations of nitrate via consumption of vegetables grown in the peninsula and the drinking water. These observations are not surprising, since a number of widely consumed staple foods are known to naturally contain nitrates with about $75 \%$ of dietary nitrate being found in vegetables. ${ }^{2: 3}$ Results obtained in the present investigation at Kalpitiya are similar to findings in a study conducted by Tejera et $a l^{24}$ and Moller $c t a l^{25}$ in a rural population of Denmark. In these studies, they found that drinking water and vegetables were two major sources of nitrates for the population under study. Massey and Lees ${ }^{2 i}$ showed that consumption of nitrate and nitrite from preservatives in cured meats and continental cheeses were very small. The dietary survey conducted in the present investigation revealed that most individuals consumed approximately $100 \mathrm{~g}$ of Anguna leaves/day which would contribute about $300 \mathrm{mg}$ nitrate. Because Kalpitiya is a very dry area, on average, each person in the area consumes 2-3 l of water/day. In the areas where wells contain $>100 \mathrm{mg}$ nitrate, a person consuming $3 \mathrm{l}$ of water/day would have an intake of at least $300 \mathrm{mg}$ nitrate from the drinking water alone. If only the daily average consumption of Anguna leaves and drinking water are taken in to consideration, a person living in an area where wells contain $>100 \mathrm{mg}$ nitrate/ would be exposed to approximately $600 \mathrm{mg}$ nitrate /day (which is a very high intake). If the nitrate content of other vegetables consumed are also taken in to account, the total daily intake of nitrates by an individual would be even higher. 
Three major factors that are generally considered to be involved in the accumulation of nitrates by plants ${ }^{27}$ are genetic factors, light factors from the ecological environment and nutritional factors. Application of fertilizer ${ }^{4}$ and other factors related to the plant itself ${ }^{28}$ are additional factors that have been shown to influence nitrate accumulation by plants.

The frequent application of nitrogenous fertilizer for agricultural purposes coupled with the closed aquifer is probably the primary factor responsible for the very high concentrations of nitrates in vegetables cultivated in the Kalpitiya peninsula and in the drinking water of the area. Moreover, the annual increase in groundwater nitrate concentrations have been suggested ${ }^{22}$ to be close to $1-2 \mathrm{mg} \mathrm{l}^{-1}$. In addition, a clear connection has been shown between the land use and groundwater quality. The maximum groundwater nitrate concentrations have been found to occur in those areas which have been intensively cultivated for the longest period of time, whereas only low or background nitrate concentrations have been found in those areas where cultivation was minimal, suggesting ${ }^{22}$ that leaching of chemical fertilizers from intensively cultivated soils are responsible for the elevated concentrations of nitrate observed in many of the irrigation dug wells in the peninsula.

Ingestion of high nitrate concentrations has been implicated in the development of methaemoglobinaemia. ${ }^{2 !}$ This condition is seen more frequently in infants than in adults due to the higher $\mathrm{pH}$ of the gastrointestinal tract in new borns favouring bacterial growth; including those (especially Escherichia coli) which converts nitrates to nitrites, the latter being responsible for methaemoglobinaemia. ${ }^{2 ! 9}$ A related observation made by Gruener ${ }^{30}$ that infants up to 6 months old when fed with powdered milk dissolved in tap water containing $>45 \mathrm{mg}$ nitrate/l developed methaemoglobinaemia which is a matter for concern. In another study carried out by us recently in the Kalpitiya peninsula ${ }^{31}$, it was found that $64 \%$ of the infants of families living in the study area have methaemeglobin levels above, the normal range, being $(0-2 \%)$.

In conclusion, the present investigation provides supportive evidence for the view that drinking water and vegetables can be sources of high nitrate intake. Health hazards associated with high nitrate exposure, apart from acute methaemoglobinaemia and cancers remain undocumented. In view of the high percentage of infants in the Kalpitiya peninsula who have abnormal methaemoglobin concentrations $>2 \%$ it would be interesting to investigate the extent of nitrate related cancers in the study area. The degree of risk depends not only on the intrinsic toxicity of nitrates and nitrites, and the intake of food products considered in the study, but also on the overall dietary intake of these chemicals, as well as $\mathrm{N}$ - nitroso compounds present in the environment. 
As a follow up to the observation made in the present study it may be necessary to impose strict control on the use of fertilizers by farmers, especially in areas with closed aquifers such as the Kalpitiya peninsula.

\section{Acknowledgement}

The financial assistance provided by NORAD on the research programme on "Nutritional and physiological effects of nitrates in the ground water at Kalpitiya" to the first author is acknowledged with thanks.

\section{References}

1. Terblanche A.P.S. (1991). Health hazards of nitrate in drinking water. Water SA. 17 (1): 77-82.

2. Kross B.C., Ayebo A.D \& Fuortes L.J. (1992 Jul). Methaemoglobinaemia: nitrate toxicity in rural America, American Family Physician 46(1): 183-8.

3. National Academy of Sciences (1981). The health effects of nitrate, nitrite and N-nitroso compounds. National Academy Press, Washington, D.C.

4. Aubert M.C. (1983). Nitrates in vegetables; some possible toxic effects. Nutrition and Health 2: 77-84.

5. Sudrand C., Sudrand P., Declercq B. \& Maillard R. (1980). Teneur en nitrates de differents vegeta, Anu. Nutr. Alimi., Paris, 34: 914

6. Menzer R.E. (1993). Water and soil pollutants. In: Casrett and Doull's Toxicology. The basic Science of Poisons (Eds: M.O. Amdur, J. Doull \& C.D. Klaasen) 4th ed, 872-902. Mc Graw Hill, New York.

7. Mirvish S.S. (1991). The significance for human health of nitrate, nitrite and N-nitroso compounds, NATO ASI series.

8. Fine D. (1980). Advances in environmental Science and Technology (Eds. J. Pitts \& R. Metcalf ), 39-123. Wiley New York.

9. Hardisson A., Gonzalez Padron A., Frias I. \& Reguera J.A. (1996). The evaluation of the content of nitrates and nitrites in food products of infants. Journal of Food Composition and Analysis 9: 13-17.

10. Hotchinkiss J. (1989). Food Toxicology (Ed. Tayler - Scanlan, Ed.) Institute of Food Technologist, 221 N. La Salle St. Chicago, Illinois. 
11. Majchrzak D., Gronowska - Senger A. \& Oleksiak K. (1991). Evaluation of nitrate and nitrite content in diets of pre-school children, Roczn Panstwowy zaklad Higieny 42 (4): 369-74.

12. Bilczuk L. \& Golacka R. (1991). Values of nitrate and nitrite in selected vegetables and potatoes cultivated in the region of Pulaw, Roczn Panstwowy zaklad Higieny 42 (3): 255-63.

13. De Alwis K. A. \& Panabokke C.R. (1972). Handbook of soils of Sri Lanka J. Soil Science Society of Ceylon 2: 41-43.

14. Tennakoon T. B. (1985). Hydrogeological investigations in Kalpitiya Regional Belt directed towards Agricultural Activities. Unpublished Water Resources Board Report, Groundwater Division, Sri Lanka.

15. Lawrence A. R. , Kuruppuarachchi D. S. P. \& Mubarak A.M. (1992). Impact of agriculture on groundwater quality: Kalpitiya Peninsula, Sri Lanka British Geological Survey, Hydrogeology Series Research Technical Report WD/92/49.

16. Piper C. S. (1950). Soil and Plant Analysis. A laboratory mannual of methods for the examination of soils and the determination of the inoraganic: constituents of plants. University of Adelaide, Adelaide. p.202

17. Kuruppuarachchi D. S. P. (1995). Study on Agro-wells in North Western Province, Presidential Address, SLAAS, Section B

18. Nagarajah S., Emerson B. N. \& Abeykoon V. (1998). Water quality of wells in Jaffna and Kilinochchi. Tropical Agriculturist, 144: 61-78

19. Dissanayaka C. B., Weerasooriya S.V.R. \& Senaratne A. (1984). The distribution of nitrate in the potable waters of Sri Lanka. Aqua 1: 43-50.

20. Gunasekaram T. (1983). Groundwater contamination and case studies in Jaffna peninsula (paper read at the IGS-WRB Workshop, Colombo)

21. Lawrence A.R., Chilton P.J. \& Kuruppuarachchi D.S.P. (1988). Review of the pollution threat to groundwater in Sri Lanka. Journal of Geological Society of Sri Lanka, L. 85-92

22. Kuruppuarachchi D.S.P \& Fernando W.A.R.N. (1999). Impact of agriculture on grundwater quality: leaching of fertilizers to groundwater in Kalpitiya peninsula, Journal of Soil Science Society of Sri Lanka, 11: 9-16. 
23. Ministry of Agriculture, Fisheries and Food (1987). Nitrate, nitrite and N-nitroso compounds in food: Second Report. Food surveillance Paper No. 32 Her Majesty's Stationary office, London.

24. Frias Tejera I., Herrera Beniteg A., Hardisson A. \& Sierra Lopez A. (1992). Niveles de concentracion in nitratos y nitritos y en sus agnus de coccion. Reviews of Toxicology 9: 65-67.

25. Moller H., Landt J., Jensen P., Pedersen E., Autrup H. \& Jensen. O.M. (1989). Nitrate exposure from drinking water and diet in a Danish rural population. International Journal of Epidemiology 18: 206-212

26. Massey R.C. \& lees D. (1992). Surveillance of preservatives and their interactions in foodstuffs. Food Additives and Contents 9: 435-440.

27. Fritsch P. \& De Saint Blan quat G. (1990). Nitrates, nitrites, nitrosamines. In Hardisson et al. (1996). The evaluation of the content of nitrates in food products of infants. Journal of food Composition and Analysis 9: 13-17

28. Bodiphala T. \& Omrod P. (1971). Factors affecting the nitrate content of vegetable and fruit foods. Canadian Institute of Food Technology Journal 4: 6-8.

29. Rosenfield A.B. \& Huston R. (1950). Infant methaemoglobinaemia and other health effects of nitrates in drinking water. Progress in Water Technology, 8 No. 4/5, 183-193.

30. Shuval H.H. \& Gruener N. (1977). Infant methaemoglobinaemia and other health effects of nitrates in drinking water. Progress in Water Technology, 8

31. Liyanage C., de Silva D.G.H., Thabrew I., Mohideen R. \& Pathirana C. (1993). Nutritional and physiological aspects of nitrate pollution in ground water at Kalpitiya. Report submitted to NORAD, Colombo. 